\title{
Application Of 5G Internet System To Improve The Economy (Case Study Of Bali Province)
}

\author{
Turkhamun Adi Kurniawan ${ }^{1}$, Popon handayani ${ }^{2}$, Pas Mahyu Akhirianto ${ }^{3}$, \\ Arman Syah Putra ${ }^{4 *}$, Nurul Aisyah ${ }^{5}$ \\ ${ }^{1}$ Faculty of Computer, Satya Negara Indonesia University, Indonesia \\ ${ }^{2}$ Faculty of Information Technology, Nusa Mandiri University, Indonesia \\ ${ }^{3}$ Faculty of Engineering \& Informatics., Bina Sarana Informatika University, Indonesia \\ ${ }^{4 *}$ Faculty of Computer, STMIK Insan Pembangunan, Indonesia \\ ${ }^{5}$ Faculty of Economic and Business, Bina Sarana Informatika University, Indonesia \\ ${ }^{*}$ Corresponding author: \\ Email: armansp892@gmail.com
}

\begin{abstract}
.
The background of this research is to know the application of $5 G$ in Denpasar Bali. With the application of $5 G$ technology, what can be obtained to help in all fields, especially in the city of Denpasar Bali. The method used in this research is to use the literature review method, and implement the existing system on the $5 G$ system in the city of Denpasar Bali. The problem raised in this research is how to find out the application of $5 \mathrm{~g}$ technology that is needed by many people based on the problem of sending data or data supply because the data is too much and too large. It is known whether $5 \mathrm{~g}$ technology can solve this problem so that it can help the community in making maximum use of data and sending data to help many things. The purpose of this research is how to find out the application of $5 G$ technology in the city of Denpasar Bali, $5 G$ technology that will be applied so that it can help many people, especially in terms of sending data and using virtual data because the data sent has started a lot and requires bigger technology. Again in sending data.
\end{abstract}

Keyword : Application, 5G, Internet System, Economy, Bali.

\section{INTRODUCTION}

Denpasar City is one of the developing cities in Indonesia in the tourism and economic sectors. The increase in economic activity and tourism causes the number of population growth and arrivals to increase every year. Along with the increase in population and the development of activities, the demand for data services for telecommunications purposes is increasing, so that the demand for land used as a green field is also increasing. But in reality the available land is very limited. On the other hand, the impact of tower construction that continues to increase will have the potential to worsen the aesthetics and spatial planning of the city [1]. Along with the development of the need for mobile data services and the high data rate in Denpasar City, it is necessary to improve the quality of information and communication networks that can serve all customer needs in quantity and quality, one of which is the availability of $5 \mathrm{G}$ network services.

This high demand and limited space and land have triggered the development of rooftop towers that have micro coverage, where the antenna height is not more than 22 meters in urban areas. One of the appropriate places for the placement of a rooftop tower is on top of a building called the banjar hall. Banjar hall is a strategic public facility to place towers, especially on the island of Bali because the Banjar halls are spread out in several locations around residential areas [2].Banjar itself is a "container" for the Balinese community to carry out activities, where the laws and regulations of the Banjar hall have been directly regulated by the government. Therefore, in addition to the rental fee that will fall into the hands of the community, the construction of a rooftop tower above the Banjar hall building is also useful for facilitating arrangements and licensing aspects [3]. In its application, a study of $5 \mathrm{G}$ coverage is needed on the placement of the Banjar hal 1 rooftop. In the 
estimation of tower coverage, it is necessary to choose the right propagation model. The propagation model is determined based on the object of research and the specifications of the rooftop tower. Several models of outdoor propagation for urban areas have been widely studied [4].

\section{THEORETICAL FOUNDATION}

In a study conducted by Septi Andi Ekawibowo in 2018, discusses the analysis of frequency band candidates on 5G NR technology that are suitable for application in Indonesia based on the conditions of the existing frequency spectrum allocation. In considering the availability of the frequency spectrum in Indonesia, which is based on three levels of candidate frequency bands for $5 \mathrm{G} \mathrm{NR}$, namely the $700 \mathrm{MHz}$ band at low frequencies; band $3.3 \mathrm{GHz}-4.2 \mathrm{GHz}$ in the medium frequency; and the band $24.25-29.5 \mathrm{GHz}$ in the high frequency, the most suitable frequency band for initial application in Indonesia is the band 3.3-4.2 GHz in the medium frequency band to meet the high capacity and coverage required for the three scenarios use of the $5 \mathrm{G}$ system [5]. Meanwhile, to meet the demands of a high data rate for eMBB where the use of cellphones is a valuable market in Indonesia, the $24.25-29.5 \mathrm{GHz}$ frequency band is the most suitable for initial application in Indonesia. The results of this study become a reference for the selection of the frequency band used in the thesis. Research in 2018 by Björn Halvarsson; Arne Simonsson; Anders Elgcrona; Ranvir Chana; Paulo Machado; and Henrik Asplund, discussing the trial of NR technology at a frequency of $3.5 \mathrm{GHz}$.

With beamforming, the increase in propagation loss at a frequency of $3.5 \mathrm{GHz}$ compared to $2.1 \mathrm{GHz}$ can be compensated and the range is shown to be equivalent to that of a $2.1 \mathrm{GHz}$ LTE fixed antenna in both outdoor and indoor conditions. Excellent coverage is demonstrated by the massive MIMO tested at $3.5 \mathrm{GHz}$ which has a downlink throughput of $700 \mathrm{MBps}$ on a carrier width of $80 \mathrm{MHz}$ and reaches a distance of $700 \mathrm{~m}$ for the LOS case. In a dense urban microcell deployment, $200 \mathrm{Mbps}$ for the case of NLOS in the same cell range. indoor coverage is also predicted to be feasible and equivalent to LTE. Research in mid-2018 by Hutchison Telephone Company Limited (HTCL) to test $5 \mathrm{G}$ NR networks in the $26 / 28 \mathrm{GHz}$ and $3.5 \mathrm{GHz}$ frequency bands in Hong Kong urban environments [6].From the measurement results, it was found that in an area of about 200 meters, the downlink speed of the $5 \mathrm{G} \mathrm{NR}$ carrier in the $3.5 \mathrm{GHz}$ band (bandwidth $100 \mathrm{MHz}$ ) is about 4-5 times greater than that of the 4G LTE carrier in the $1.8 \mathrm{GHz}$ band (bandwidth 2 x10MHz). With the Non-Standalone (NSA) network architecture option based on the 3GPP 15 standardization release, it was found that the $3.5 \mathrm{GHz}$ band has better coverage range than the $28 \mathrm{GHz}$ band. This $26 / 28 \mathrm{GHz}$ band has small coverage due to high propagation loss and penetration loss. However, when compared to $4 \mathrm{G}$ carriers in the $1.8 \mathrm{GHz}$ band, measurements show $5 \mathrm{G}$ carriers have comparable coverage, much better speeds and a better user experience. For the $26 / 28 \mathrm{GHz}$ band, very high download speeds of $4.8 \mathrm{Gbps}$ and $3.2 \mathrm{Gbps}$ respectively in indoor and outdoor environments [7].

\section{METHODS}

The research was conducted in the Denpasar city area, starting in May 2019. The data sources obtained were grouped into secondary data and primary data. Primary data is data obtained directly by surveying locations, namely in the form of the coordinates of each Banjar and the point of spreading the rooftop tower for the Denpasar area. Secondary data was obtained from the literature with references to books, journals, papers and browsing results on the internet that supported the analysis during the research.

The initial step taken is to determine the parameters to be used during the analysis, namely frequency, fade margin, sensitivity, received signal strength, transmitted signal strength, transmitting antenna gain, receiving antenna gain, electromagnetic wave length, shadowing loss. And the area of Denpasar. Next, calculate the radius using a propagation model for path losses and shadowing, calculate coverage, calculate the number of rooftop towers in Denpasar City, and map rooftop towers in Denpasar City using Google Earth. 


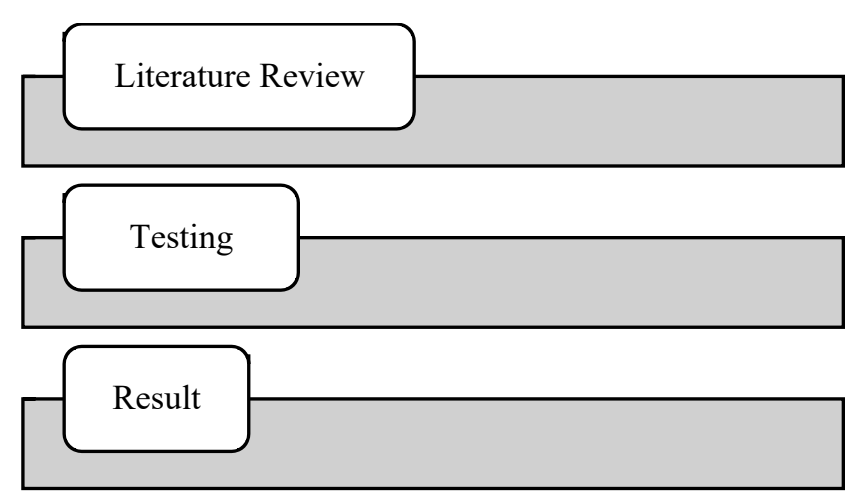

Fig 1. Research Method

\section{DEVELOPMENT}

A research method for $5 \mathrm{G}$ network coverage in the city of Denpasar. In my opinion, as explained in Chapter 3 related to the research method, there are still variables that have not been listed, such as the implementation of the mobile phone of residents who have not met the verification of the $5 \mathrm{G}$ internet. And also if it is correlated with current conditions, conducting a survey in the field is a little difficult because there are health protocols. And at this stage, the author will add a method for researching $5 \mathrm{G}$ network coverage more easily based on the current situation.

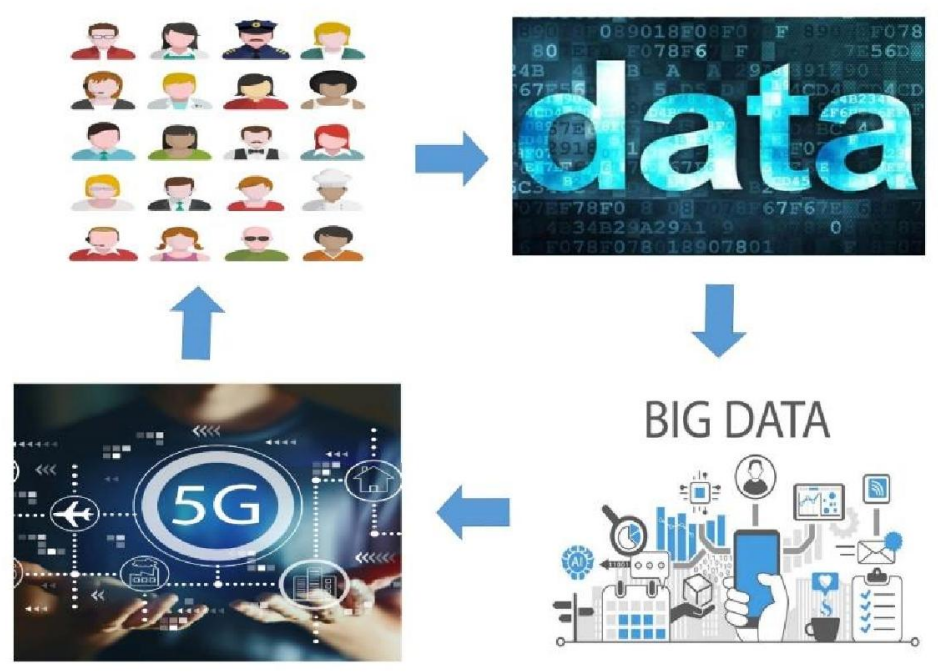

Fig 2. Framework $5 \mathrm{G}$

1. Survey here means to conduct a survey with existing data from previous years. That is by looking at visitor data in the city of Denpasar, as well as local residents who use adequate devices or cellphones. Because if the reach and the network is wide, but the users are few, it becomes less effective. And also some other things, namely.

2. Geographical Conditions the city of Denpasar is known for its beautiful natural beauty, but if you want to expand your reach in that area, you need to have a large number of rooftop towers spread throughout the city.

3. Radio Frequency Spectrum is an important asset for communication service providers. The radio frequency spectrum for $5 \mathrm{G}$ covers different frequency ranges, each with different characteristics. Each of the three components comes to the market in a materially different way, in terms of performance and coverage. In early deployments, coverage is a major factor.

4. High Band for revolutionary creativity First, the high band spectrum is suitable for increasing outdoor capacity in urban areas with a high concentration of users, such as train and bus stations, central business 
districts, and around landmarks. Second, high band can provide fixed broadband for business and residential areas in suburban areas that are not yet covered by fiber optic networks, and are installed one by one in a residential area. Third are areas that require high data usage, where $5 \mathrm{G}$ can provide new business value such as in factories, warehouses, sports venues, universities, hospitals, and so on - where cables are too static and alternative wireless technologies are too slow, or not very good. Reliable or very unsafe.

5. Mid band for phenomenal capacity $5 \mathrm{G}$ also has the opportunity to increase phenomenal capacity throughout the metropolitan area. The mid band spectrum is perfect for providing smooth cellular network coverage in metropolitan areas and along highways. You can expect speeds in the hundreds of megabits per second for a few miles on the mid band 5G spectrum. Customers can have $5 \mathrm{G}$ access, both outdoors and indoors.

6. Low band for great coverage the scenario of network deployment in low band is suitable for national coverage, in metropolitan areas, small cities, and rural areas. The low band spectrum will be constructed in a similar way to the way $1 \mathrm{G}$ and $2 \mathrm{G}$ were introduced a few decades ago - with an initial focus on coverage. We can expect increased $4 \mathrm{G}$ performance, with a range of up to around 16 kilometers. This spectrum provides outdoor and indoor coverage of large towers.

7. 5G Security in essence, $5 \mathrm{G}$ is different from previous generation technologies. The $5 \mathrm{G}$ network will serve as a critical infrastructure to facilitate the digitization, automation and connectivity of machines, robots, transportation solutions, and so on. For that, there are important things at stake, and, as such, a different risk tolerance is required. Security is becoming increasingly important in the $5 \mathrm{G}$ era as security threats continue to evolve, infrastructure and business risks continue to increase, regulatory requirements increase, deployment scenarios and new use cases are created, billions of new devices, and cloud-related challenges.

8. $5 \mathrm{G}$ for Users and Business The launch of $5 \mathrm{G}$ opens up new opportunities for society. Our research points to key opportunities in the areas of: Enhanced Video (4K, $8 \mathrm{~K}$ and 360-degree formats), Live Sports Streaming, Music and Gaming (mobile and cloud), Augmented and Virtual Reality (AR/VR), Consumer IoT Services, Entertainment and Connectivity in the car, and Digital Advertising. Therefore, 5G is becoming an "ecosystem play" that provides communication service providers with new opportunities to increase revenue beyond their traditional domains of connectivity and mobility. In addition, 5G will also change business massively. Following are some of the emerging characteristics of a 5G-enabled business: being able to run any process remotely (regardless of how critical the process is), having actual real-time control of every business process, fully automated operation, using compute resources, and last but not least, have a higher level of security without compromising overall performance.

\section{CONCLUSION}

From the results of the analysis of the method above, we can conclude that with the wide reach of $5 \mathrm{G}$ Internet in the city of Denpasar, we get a lot of benefits, not only in the business sector, but from the eyes of tourists and the world that Bali, which is majestic, is glorified by the people of Indonesia and the people of the world., the Bali area, especially the city of Denpasar, which is a metropolitan city of Bali, is not outdated. Moreover, the most important thing is the security of the $5 \mathrm{G}$ Internet.

\section{REFERENCES}

[1] Armaita, H. Dedi , B. Eri , D. Indang and U. Iswandi, "Policy Model of Community Adaptation using AHP in the Malaria Endemic Region of Lahat Regency -Indonesia," International Journal of Management and Humanities (IJMH), pp. 44-48, 2020.

[2] H. W. Arman Syah Putra, "“Intelligent Traffic Monitoring System (ITMS) for Smart City Based on IoT Monitoring"," 1st 2018 Indonesian Association for Pattern Recognition International Conference, INAPR 2018 - Proce vol, 2019.

[3] H. W. F. G. B. S. E. A. Arman Syah Putra, "A Proposed surveillance model in an Intelligent Transportation System (ITS)"," 1st 2018 Indonesian Association for Pattern Recognition International Conference, INAPR, 2019. 
[4] A. Damuri, N. Isnain, R. A. Priyatama, Y. I. Chandra and A. S. Putra, "E-Learning Proposal System in Public Secondary School Learning," International Journal of Educational Research \& Social Sciences (IJERSC), vol. 2, p. 270-275, 2021.

[5] N. K. Dewi and A. S. Putra, "Prosiding International Conference of Universitas Pekalongan," Prosiding International Conference on Education of Suryakancana 2021 (ICONNECTS 2021), pp. 321-326, 2021.

[6] K. Jacksi, M. A. Sulaiman and R. H. Saeed, "The Importance of E-Learning in the Teaching Processor Secondary Schools /Review Article," Academic Journal of Nawroz University (AJNU), Vol.10, No.1, Jan 2021, vol. 10, pp. 5362, 2021.

[7] A. S. Putra, "Efektifitas Sistem Jalan Underpass untuk Kota Pintar DKI Jakarta," Jurnal Informatika Universitas Pamulang, vol. 5, no. 3, pp. 220-227, 2020.

[8] R. Hermawan, M. T. Habibie, D. Sutrisno, A. S. Putra and N. Aisyah, "Decision Support System For The Best Employee Selection Recommendation Using Ahp (Analytic Hierarchy Process) Method," International Journal of Educational Research \& Social Sciences, vol. 2, no. 5, pp. 1218-1226, 2021.

[9] D. Katarina, A. Nurrohman, w. and A. S. Putra, "Decision Support System For The Best Student Selection Recommendation Using Ahp (Analytic Hierarchy Process) Method," International Journal of Educational Research \& Social Sciences, vol. 2, no. 5, pp. 1210-1217, 2021.

[10] H. Sugiarto, I. Sumadikarta, M. Ryansyah, M. H. Fakhriza and A. S. Putra, "Application Design" Test Job Application" On Android OS Using The AHP Algorithm," International Journal of Educational Research \& Social Sciences, vol. 2, no. 5, pp. 1173-1180, 2021.

[11] W. E. Pangesti, R. Suryadithia, M. Faisal, B. A. Wahid and A. S. Putra, "Collaborative Filtering Based Recommender Systems For Marketplace Applications," International Journal of Educational Research \& Social Sciences, vol. 2, no. 5, pp. 1201-1209, 2021.

[12] R. Wirawan, N. Aisyah, A. Rahman, B. S. Rahmawati, A. Medikano, A. Sebayang and A. S. Putra, "Perancangan Aplikasi Website Menggunakan Macromedia Dreamweaver Mx Untuk Budi Daya Anggrek (Studi Kasus Toko Anggrek Berseri)," TEKINFO, vol. 22, no. 2, pp. 77-86, 2021.

[13] A. Saputra, A. Fahrudin, A. S. Putra, N. Aisyah and V. Valentino, "The Effectiveness of Learning Basic Mathematics through Dice Games for 5-6 Years Old at TKIT Al-Muslim," International Journal of Educational Research \& Social Sciences, vol. 2, no. 6, pp. 1698-1703, 2021.

[14] B. Givan, R. Amalia, A. I. Sari, S. H. Winarno and A. S. Putra, "Effective Use of E-Money through Online Shopping in E-Commerce," International Journal of Educational Research \& Social Sciences, vol. 2, no. 6, pp. 1692-1697, 2021.

[15] N. Zhang, X. Zhao, T. Liu, M. Lei, C. Wang and Y. Wang, "Layout Planning of Highway Transportation," Sustainability 2020, 12, 290, pp. 1-25, 2020.

[16] Y. H. Yeni and V. Pujani, "Examination of Business Student's Satisfaction to Use E-Learning; Empirical Study during Covid 19- Pandemic in Universitas Andalas," Proceedings of the 3rd International Conference on Educational Development and Quality Assurance (ICED-QA 2020), vol. 506, no. 1, pp. 186-190, 2020.

[17] Z. YANG and X. WANG, "Influence of Metro Tunnel Excavation on Deformation of Existing Pedestrian Underpass in Changzhou Railway Station Platform," ACCESS.2020.2981343, pp. 55860-55871, 2020.

[18] A. Wirara, B. Hardiawan and M. Salman, "Identifikasi BuktiDigital pada Akuisisi Perangkat Mobile dari Aplikasi Pesan Instan "WhatsApp"," eknoin Vol. 26, No. 1, Maret2020: , pp. 66-74, 2020.

[19] I. M. S. Wibawa, I. W. Redana, P. . A. Suthanaya and N. M. A. Wiryasa, "Understanding Vertical Holiness as a Received Business on Underpass Development," International Journal of Engineering and Emerging Technology, Vol. 5, No. 1, January-June 2020, pp. 50-56, 2020.

[20] V. Valentino, H. S. Setiawan, . A. Saputra, Y. Haryanto and A. S. Putra, "Decision Support System for Thesis Session Pass Recommendation Using AHP (Analytic Hierarchy Process) Method," Journal International Journal of Educational Research \& Social Sciences, pp. 215-221, 2021.

[21] . V. H. Valentino, H. S. Setiawan, M. T. Habibie, R. Ningsih, D. Katarina and A. S. Putra, "Online And Offline 
Learning ComparisonIn The New Normal Era," International Journal of Educational Research \& Social Sciences (IJERSC), vol. 2, no. 2, p. 449-455, 2021.

[22] M. Ulfa, "“Pengaruh Kecanduan Game Online Terhadap Perilaku Remaja Di Mabes Game Center Jalan Hr.Subrantas Kecamatan Tampan Pekanbaru"," Jom. Fisip Vol. 4 No. 1, pp. 1-13, 2017.

[23] A. I. Tjahjani and S. , "KAJIAN MASA KONSTRUKSI REKAYASA LALU LINTAS," Prosiding Simposium Forum Studi Transportasi antar Perguruan Tinggi ke-20 Universitas Hasanuddin, Makassar, 4 - 5 November 2017, pp. 663670, 2017.

[24] R. M. Tawafak, "A Combined Model for Continuous Intention to Use E-Learning System," IJIM , vol. 15, no. 3, pp. 113-129, 2021.

[25] R. N. Suryanto, "“Dampak Positif Dan Negatif Permainan Game Online Dikalangan Pelajar"," Jom Fisip Volume 2 No. $2,2015$.

[26] M. A. Suplig, "“Pengaruh Kecanduan Game Online Siswa Sma Kelas X Terhadap Kecerdasan Sosial Sekolah Kristen Swasta Di Makassar"," Jurnal Jaffray, Vol. 15, No. 2,, pp. 77-200, 2017.

[27] M. Subani, I. Ramadhan, S. and A. S. Putra, "Perkembangan Internet of Think (IOT) dan Instalasi Komputer Terhadap Perkembangan Kota Pintar di Ibukota Dki Jakarta," IKRA-ITH INFORMATIKA: Jurnal Komputer dan Informatika, vol. 5, no. 1, pp. 88-93, 2020.

[28] H. S. Setiawan, "“Analisis Dampak Pengaruh Game Mobile Terhadap Aktifitas Pergaulan Siswa Sdn Tanjung Barat 07 Jakarta"," P-Issn: 1979-276x, E- Issn: 2502-339x, Doi: 10.30998/Faktorexacta.V11i2.2338, pp. 146-156, 2018.

[29] I. M. Sari and E. D. Prajayanti, "PENINGKATAN PENGETAHUAN SISWA SMP TENTANG DAMPAK NEGATIF GAME ONLINE BAGI KESEHATAN," Program Studi Keperawatan, STIKES 'Aisyiyah Surakarta, pp. 1-9, 2017.

[30] E. Rubawati, "Media Baru: Tantangan dan Peluang Dakwah," Jurnal Studi Komunikasi http://ejournal.unitomo.ac.id/index.php/jsk, pp. 126 - 142, 2018.

[31] P. Roza, "DIGITAL CITIZENSHIP: MENYIAPKAN GENERASI MILENIAL MENJADI WARGA NEGARA DEMOKRATIS DI ABAD DIGITAL," Journal Sosioteknologi Volume 19, No 2, Agustus 2020, pp. 190-202, 2020.

[32] P. M. Risnadinata, I. Kumara and W. Ariastina, "Management of Flood Protection System of Dewa Ruci Underpass in Bali," Journal of Electrical, Electronics and Informatics, Vol. 4 No. 2, August 2020, pp. 57-63, 2020.

[33] D. D. A. P. Riani Muharomah, "“Analisis Run-Off Sebagai Dampak Perubahan Lahan Sekitar Pembangunan Underpass Simpang Patal Palembang Dengan Memanfaatkan Teknik Gis"," 2014.

[34] M. H. Riandi, H. Respati and S. Hidayatullah, "Conceptual Model of User Satisfaction as Mediator of E-Learning Services and System Quality on Students' Individual Performance," International Journal of Research in Engineering, Science and Management, vol. 4, no. 1, pp. 60-65, 2021.

[35] I. Ramadhan, A. Kurniawan and A. S. Putra, "Penentuan Pola Penindakan Pelanggaran Lalu Lintas di DKI Jakarta Menggunakan Metode Analytic Network Process (ANP)," IKRA-ITH INFORMATIKA: Jurnal Komputer dan Informatika, vol. 5, no. 1, pp. 51-57, 2020.

[36] A. S. Putra, "Konsep Kota Pintar Dalam Penerapan Sistem Pembayaran Menggunakan Kode QR Pada Pemesanan Tiket Elektronik," TEKINFO Jurnal Ilmiah Teknik Informatika, vol. 21, pp. 1-15, 2020.

[37] A. S. Putra, "Teknologi Informasi (IT) Sebagai Alat Syiar Budaya Islam Di Bumi Nusantara Indonesia," Seminar Nasional Universitas Indraprasta ( SINASIS ), pp. 200-215, 2020.

[38] A. S. Putra, "Peran Sosial Media Sebagai Media Dakwah Di Zaman Pandemic Virus Corona Atau Covid 19 Di Indonesia," Panangkaran: Jurnal Penelitian Agama dan Masyarakat, pp. 1-12, 2021.

[39] A. S. Putra, "PENTING NYA KESADARAN HUKUM RAKYAT INDONESIA DI BIDANG TEKNOLOGI INFORMASI DI TINJAU DARI KEBERADAAN CYBERCRIME," Seminar Nasional Inovasi dan Teknologi (SNIT) BSI, pp. 36-50, 2012.

[40] A. S. Putra and . H. Kusuma, "Pengembangan Sistem Career Center untuk Departemen Konseling dan Pengembangan Karir di Institut Teknologi Budi Utomo," Jurnal Khatulistiwa Informatika, pp. 133-143, 2015.

[41] A. S. Putra, "Penerapan Konsep Kota Pintar dengan Cara Penerapan ERP (Electronic Road Price) di Jalan Ibu Kota 
International Journal Of Science, Technology \& Management

ISSN: $2722-4015$

DKI Jakarta. Jurnal Informatika Universitas Pamulang, 5(1), 13-18.," Jurnal Informatika Universitas Pamulang, 5(1), 13-18., pp. 13-18, 2020.

[42] A. S. Putra and . R. R. Fatrilia, "Paradigma Belajar Mengaji Secara Online Pada Masa Pandemic Coronavirus Disease 2019 (Covid-19)," MATAAZIR: Jurnal Administrasi dan Manajemen Pendidikan, pp. 49-61, 2020.

[43] A. S. Putra and L. H. S. W. Harco , "Intelligent Traffic Monitoring System (ITMS) for Smart City Based on IoT Monitoring," Indonesian Association for Pattern Recognition International Conference (INAPR) IEEE, pp. 161-165, 2018.

[44] A. S. Putra, L. H. S. W. Harco, S. A. Bahtiar, T. Agung, . S. Wayan and H. K. Chu-, "Gamification in the e-Learning Process for children with Attention Deficit Hyperactivity Disorder (ADHD)," Indonesian Association for Pattern Recognition International Conference (INAPR) IEEE, pp. 182-185, 2018.

[45] A. S. Putra, L. H. S. W. Harco, L. G. Ford, . S. Benfano and A. Edi, "A Proposed surveillance model in an Intelligent Transportation System (ITS)," Indonesian Association for Pattern Recognition International Conference (INAPR) IEEE, pp. 156-160, 2018.

[46] A. S. Putra, "“Penggabungan Wilayah Kota Bekasi Dan Kota Tangerang Ke Wilayang Ibu Kota DKI Jakarta Berdasarkan Undang-Undang Nomor 23 Pasal 32 Tahun 2019 Dapat Membantu Mengwujudkan DKI Jakarta Menjadi Kota Pintar"," Jurnal IPSIKOM Vol 7 No. 2, 2019.

[47] A. S. Putra, H. L. H. S. Warnars, B. S. Abbas, A. Trisetyarso, W. Suparta and C.-. Ho Kang, "“Gamification in the eLearning Process for children with Attention Deficit Hyperactivity Disorder (ADHD)"," 1st 2018 Indonesian Association for Pattern Recognit INAPR, pp. 182-185, 2019.

[48] A. S. Putra, " "Smart City : konsep Kota pintar di DKI Jakarta"," Jurnal TEKINFO, Vol 20, No 2, Hal 1-111, ISSN 1411-3635, 2019.

[49] A. S. Putra, " "Smart City : Ganjil Genap Solusi Atau Masalah Di DKI Jakarta"," Jurnal IKRA-ITH Informatika Vol 3 No 3, ISSN 25804316 , , 2019.

[50] D. W. Pratomo, R. Lim and T. , "Sistem Akses Parkir dengan QR Code," Jurnal Teknik Elektro, Vol. 13, No. 1, Maret 2020, 8-13, pp. 8-13, 2020.

[51] N. A. Prabowo, P. Hendradi and B. Pujiarto, "Kerangka Model Aplikasi E-Dakwah Pengembangan Kaderisasi Pada Pengurus Daerah Muhammadiyah Kota Magelang," Indonesian Journal on Networking and Security - Volume 8 No 3 -2019, pp. 1-8, 2019.

[52] Nurnainah, "PENYULUHAN TENTANG DAMPAK BERMAIN GAME ONLINE," Jurnal Peduli Masyarakat Volume 2 Nomor 2, Juni 2020 e-ISSN 2721-9747; p-ISSN 2715-6524, pp. 87-90, 2020.

[53] D. Novitasari, A. Masduki , P. AGUS , I. Joni , S. Didi , . S. Nelson and S. P. Arman , "Peran Social Support terhadap Work Conflict, Kepuasan dan Kinerja," JPIM (JURNAL PENELITIAN ILMU MANAJEMEN), pp. 187-202, 2020.

[54] L. Nisiotis, L. Alboul and M. Beer, "A Prototype that Fuses Virtual Reality, Robots, and Social Networks to Create a New Cyber-Physical-Social Eco-Society System for Cultural Heritage," Sustainability 2020, 12, 645; doi:10.3390/su12020645, pp. 1-15, 2020.

[55] B. T. Moh. and Hozairi, "IMPLEMENTASI METODE ANALYTICAL HIERARCY PROCESS (AHP) UNTUK ANALISIS FAKTOR KEAMANAN LAUT INDONESIA," Jurnal JATIM, Vol.1 No.1 April 2020, pp. 9-18, 2020.

[56] Ma'fiyah, "Urgensi Pendidikan Agama Dalam Pembentukan Akhlak Generasi Milenial," Prosiding Seminar Nasional, Harmonisasi Keberagaman dan Kebangsaan bagi Generasi Milenial,, pp. 137-143, 2019.

[57] F. M. Salman and S. S. Abu-Naser, "Expert System for COVID-19 Diagnosis," International Journal of Academic Information Systems Research (IJAISR), pp. 1-13, 2020.

[58] E. K. Laksanawati and S. P. Arman, "ANALISA STUDI CONFORMITY OF PRODUCTION (COP) UNTUK DITERAPKAN DI BALAI PENGUJIAN LAIK JALAN DAN SERTIFIKASI KENDARAAN BERMOTOR (BPLJSKB) BEKASI," Prosiding Seminar Nasional Aplikasi Sains \& Teknologi (SNAST), pp. 207-214, 2014.

[59] D. E. Kurniawan, "'Pengaruh Intensitas Bermain Game Online Terhadap Perilaku Prokrastinasi Akademik Pada Mahasiswa Bimbingan Dan Konseling Universitas Pgri Yogyakarta", Jurnal Konseling Gusjigang Vol. 3 No. 1 (Januari-Juni 2017) Print Issn 246, 2017. 
[60] A. M. Khasawneh, . O. Kaiwartya , . A. Khalifeh, . L. M. Abualigah and . J. Lloret , "Green Computing in Underwater Wireless Sensor Networks Pressure Centric Energy Modeling," IEEE Systems Journal, pp. 1 - 11, 2020.

[61] N. Ismi and A. , "Dampak Game online terhadap Perilaku Siswa di Lingkungan SMA Negeri 1 Bayang," Journal of Civic Education (ISSN: 2622-237X) Volume 3 No. 1 2020, pp. 1-10, 2020.

[62] M. S. Hartawan, A. S. Putra and A. Muktiono, "Smart City Concept for Integrated Citizen Information Smart Card or ICISC in DKI Jakarta," International Journal of Science, Technology \& Management, pp. 364-370, 2020.

[63] B. Givan, . R. Wirawan, D. Andriawan, N. Aisyah, A. and A. S. Putra, "Effect of Ease And Trustworthiness To Use ECommerce for Purchasing Goods Online," International Journal of Educational Research \& Social Sciences (IJERSC), vol. 2, no. 2, p. 277-282, 2021.

[64] K. G. B. Giri and M. Dharmadi, "GAMBARAN KETAJAMAN PENGLIHATAN BERDASARKAN INTENSITAS BERMAIN GAME SISWA LAKI-LAKI SEKOLAH MENENGAH PERTAMA DI WILAYAH KERJA PUSKESMAS GIANYAR I BULAN MARET - APRIL 2013," Program Studi Pendidikan Dokter Fakultas Kedokteran Universitas Udayana, pp. 1-7, 2013.

[65] H. W. Fauzi, S. and S. Anwar, "ANALISIS PENGEMBANGAN JALAN TIDAK SEBIDANG (UNDERPASS) DI JALAN JENDERAL SUDIRMAN - JALAN SULTAN AGUNG KABUPATEN BREBES," Jurnal Konstruksi, Vol. VI, No. 3, Januari 2017, pp. 255-268, 2017.

[66] I. Dhamayanthie, "DAMPAK GAME ONLINE TERHADAP PERILAKU MAHASISWA AKAMIGAS BALONGAN," Jurnal Rekayasa, Teknologi, dan Sains VOLUME 4 NOMOR 1, JANUARI 2020, pp. 13-15, 2020.

[67] P. K. Dhamarsa, Safrizal, . S. P. Arman and Suyanto, "Perancangan Aplikasi ITBU Career Center Berbasis Website Menggunakan PHP dan MYSQL," TEKINFO UPI YAI, pp. 1-105, 2019.

[68] N. K. Dewi and A. S. Putra, "SISTEM PENUNJANG KEPUTUSAN PENERIMAAN KARYAWAN BARU DENGAN ALGORITMA GREEDY," Jurnal Visualika, vol. 6, no. 2, pp. 154-160, 2020.

[69] N. K. Dewi and A. S. Putra, "Perkembangan Gamification dan Dampak Game Online terhadap Jiwa Manusia di Kota Pintar DKI Jakarta," Jurnal Informatika Universitas Pamulang, vol. 5, no. 3, pp. 315-320, 2020.

[70] N. K. Dewi, I. Mulyana, A. S. Putra and F. R. Radita, "Konsep Robot Penjaga Toko Di Kombinasikan Dengan Pengendalian Virtual Reality (VR) Jarak Jauh," IKRA-ITH INFORMATIKA: Jurnal Komputer dan Informatika, vol. 5, no. 1, pp. 33-38, 2020.

[71] N. K. Dewi and A. S. Putra, "LAW ENFORCEMENT IN SMART TRANSPORTATION SYSTEMS ON HIGHWAY," Proceedings International Conference onEducation of Suryakancana 2021, pp. 321-326, 2021.

[72] N. K. Dewi, . B. H. Irawan, E. Fitry and A. S. Putra, "Konsep Aplikasi E-Dakwah Untuk Generasi Milenial Jakarta," IKRA-ITH INFORMATIKA: Jurnal Komputer dan Informatika, vol. 5, no. 2, pp. 26-33, 2020.

[73] N. K. Dewi and A. S. Putra, "Decision Support System for Head of Warehouse Selection Recommendation Using Analytic Hierarchy Process (AHP) Method," Prosiding International Conference of Universitas Pekalongan, pp. 1-12, 2021.

[74] T. C Motoh, F. Jurnadi and A. Fatmawati, "DAMPAK GAME ONLINE TERHADAP SISWA KELAS XI IIS 1 SMA NEGERI 3 TOLITOLI," NUSANTARA: Jurnal IImu Pendidikan VOL. 1, NO. 1, JULI 2020, pp. 1-5, 2020.

[75] A. Burghardt, D. Szybicki, P. Gierlak, K. Kurc, P. Pietru's and R. Cygan, "Programming of Industrial Robots Using Virtual," www.mdpi.com/journal/applsci, pp. 1-12, 2020.

[76] A. Asmar, "EKSPRESI KEBERAGAMAN ONLINE: MEDIA BARU DAN DAKWAH," Jurnal Ilmu Dakwah Volume 40 No 1 (2020), pp. 54-64, 2020.

[77] D. N. M. A. A. P. J. I. D. H. S. Y. C. Arman Syah Putra, "“Examine Relationship of Soft Skills, Hard Skills, Innovation and Performance: the Mediation Effect of Organizational Le," IJSMS, pp. 27-43, 2020.

[78] T. Aprilianto, F. and W. Syahindra, "Dampak Game Online terhadap Pola Belajar Anak: Studi di Desa Ujung Tanjung III Kabupaten Lebong," $\boldsymbol{J} \boldsymbol{U} \boldsymbol{R} \boldsymbol{A} \boldsymbol{L} \boldsymbol{H} \boldsymbol{A} \boldsymbol{W} \boldsymbol{A}$, pp. 64-80, 2020.

[79] W. Rahayu, "Rancang Bangun Sistem Informasi Akademik Pada SMK Citra Dharma Berbasis JAVA," Jurnal Teknologi Informasi, Vol. 5, No. 2, Desember 2019, E-ISSN 2623-1700, pp. 85-92, 2019. 
[80] A. S. Putra, "Analisa Dan Perancangan Sistem Pembelian Makanan Di Restoran Pada Masa Pandemic Coronavirus Disease 2019 (Covid-19)," Jurnal Esensi Komputasi (Jurnal Esensi Sistem Komputer dan Informasi), vol. 4, no. 2, pp. 10-15, 2020.

[81] A. S. Putra, H. Warnars, F. Gaol, B. Soewito and E. Abdurachman, "A Proposed surveillance model in an Intelligent Transportation System (ITS)," 1st 2018 Indonesian Association for Pattern Recognition International Conference, INAPR 2018 - Proce vol. , 25, pp. 1-10, January 2019.

[82] G. L. Ondang, B. J. Mokalu and S. Y. V. I. Goni, "DAMPAK GAME ONLINE TERHADAP MOTIVASI BELAJAR MAHASISWA JURUSAN SOSIOLOGI FISPOL UNSRAT," Jurnal Holistik ISSN: 1979-0481, pp. 1-15, 2020.

[83] V. Y. Enderzon, "IDENTIFIKASI RISIKO PROYEK KONSTRUKSI FLYOVER DAN UNDERPASS DI INDONESIA (KAJIAN LITERATUR)," REKAYASA SIPIL / Volume 14, No.2 - 2020 ISSN 1978 - 5658, pp. 104-111, 2020.

[84] T. R. Arief and W. A. Rosyadi, "Reservasi Area Parkir Berbasis Internet Of Things," JE-Unisla|Vol 5 No 2 September 2020 | 370, pp. 370-375, 2020. 